\title{
Food security and trade policies: evidence from the milk sector case study
}

\section{Maria Bruna Zolin, Danilo Cavapozzi and Martina Mazzarolo Ca' Foscari University of Venice, Venice, Italy}

\begin{abstract}
Purpose - Milk is one of the most produced, consumed and protected agricultural commodities worldwide. The purpose of this paper is to assess how trade-opening policies can foster food security in the Chinese milk sector.

Design/methodology/approach - The empirical evidence proposed in our paper is based on time series data from the National Bureau of Statistics of China (2019) and FAOSTAT (2020). Differences in income elasticity between urban and rural areas are estimated by OLS regressions. The data also provide empirical evidence to assess to what extent and to which countries China is resorting to meet its growing demand.

Findings - Per-capita milk consumption of Chinese is rising. The authors' estimates show that milk income elasticity is higher in rural areas. China is also progressively increasing its dependence on imports. Producers who benefit the most are those from countries implementing trade-opening policies.

Research limitations/implications - Other methods could be applied, by way of example, the gravitational model.

Practical implications - Trade agreements and the removal of barriers could be effective responses to protectionist pressures and to food security concerns.

Social implications - The case examined is of particular interest as it intervenes on food security and safety. Originality/value - The paper adds value and evidence to the effects of trade on food security in a country with limited and exploited natural resources addressing a health emergency and environmental concerns.
\end{abstract}

Keywords Food security, Trade barriers, Milk, China

Paper type Research paper

\section{Introduction}

The rapid worldwide spread of the coronavirus (COVID-19) is threatening to increase the millions of people already vulnerable to food insecurity, malnutrition and to the effects of conflicts and other natural disasters. COVID-19 is worsening the current food insecurity, in particular, of the poorest and most food insecure countries. Labour shortages, transport limitations and restrictions on market access could alter the supply chain, emphasising the need for secure supplies (UN, 2020). Even if the large majority of people suffering from food insecurity are located in Asia, food insecurity in China remains at rather low levels with some disparities still between urban and rural areas. Despite this, food security remains a central priority of the Chinese policy (Fengying et al., 2010; Gandhi and Zhou, 2014; He et al., 2016; Zhang, 2019), which relies more than ever on the domestic market and its consumers. Food security in China is threatened by several factors, such as income and population growth, increasing urbanisation, changes in land use and water scarcity, pollution, lifestyle changes and consumption patterns. Moreover, the health crisis has affected the global food trade and supply chain, raising international food prices. Some countries (such as Russia, Ukraine and

(C) Maria Bruna Zolin, Danilo Cavapozzi and Martina Mazzarolo. Published by Emerald Publishing Limited. This article is published under the Creative Commons Attribution (CC BY 4.0) licence. Anyone may reproduce, distribute, translate and create derivative works of this article (for both commercial and non-commercial purposes), subject to full attribution to the original publication and authors. The full terms of this licence may be seen at http://creativecommons.org/licences/by/4.0/legalcode
Food security and trade policies 
BFJ

123,13
Vietnam) have adopted severe restrictions on food exports, which have also affected the Chinese market and increased concerns about the country's food security (Wang, 2020).

China is experiencing growing per capita milk consumption, leading to significant improvements in human health. However, the exponential rise in milk demand is posing a new challenge to Chinese food security. Indeed, it could severely compromise the selfsufficiency in this sector, due to the limitation of natural resources and the growing environmental concerns associated with increased domestic production. This may require China to expand its imports (Gale and Huang, 2007; He et al., 2016). In the direction of enlarged trade flows, since the early 2000s, China has been developing a considerable number of trade agreements intended to remove trade barriers and strengthen economic cooperation with other economies (Huang et al., 2017; Huang and Yang, 2017; Margulis, 2017).

This paper focuses on milk sector. Milk is a soft commodity with high levels of protectionism and support in many countries across the world (Cavapozzi et al., 2020). The aim is to analyse this sector in China as a case study to verify whether and by how much the elimination of trade barriers allows a country to achieve food security, despite growing demand trends and national production constraints. As is well-known, the global food crisis of 2007/2008 led to protectionist measures that hampered the area of food security and contributed to the sudden and rapid rise in food prices (Weiming and Ying, 2012; Anderson et al., 2013). The current situation has seen an increase in protectionist policies, and this is destined to become more acute because of the economic crisis fuelled by emergency health impacts. Trade wars and barriers have proven to be huge threats to food security.

The structure of the paper is the following. Section 2 describes data and methods. Section 3 offers a literature review of the Chinese food security and the ongoing changes in the Chinese diets. Our main findings are presented and discussed in Section 4: we first describe the evolution of the milk sector in China over the last two decades and then comment on the time series of China's milk imports from its top suppliers in the same period, placing particular attention on the changes associated with the removal of trade barriers. Finally, the concluding remarks are reported in Section 5.

\section{Data and methods}

\subsection{Data}

The empirical evidence proposed in our paper is based on time series data from the National Bureau of Statistics of China (2019) and FAOSTAT (2020). Among all the institutions collecting data on food security and the dairy market, we selected these sources in order to guarantee the data comparability over the time window of interest (2000-2018, whenever feasible based on our data sources, otherwise 2000-2017). Raw data have been downloaded from the web sources indicated within the references between January and March 2020 and then combined to define the variables discussed in our analysis.

\subsection{Methods}

The empirical evidence provided in the paper is descriptive. We use graphical representation techniques (line charts and bar charts) to analyse how the outcomes of interest vary over time and across countries. We provide empirical evidence to assess to what extent and to which countries China is resorting to meet its growing demand. Moreover, we estimate the income elasticity of the per-capita consumption of milk, grain and meat for Chinese rural and urban households. For each food item, we estimated by ordinary least squares (OLS) the linear regression of the natural logarithm of per-capita consumption on a constant term and the natural logarithm of the national per-capita GDP, which we use as a measure of per-capita 
income. The coefficient on this variable in the regression model can be interpreted as the income elasticity of per-capita consumption.

\section{Literature review: food security and China}

The significant Chinese economic growth has led to an increase in the per capita GDP, accompanied by a reduction in the poverty rate, which fell from $88 \%$ to $0.7 \%$ from 1981 to 2015 (FAO et al., 2019). This has contributed to China's relative lower incidence of food insecurity at the national level: FAO data show that in 2018, the total number of food insecure people in China constituted $9.6 \%$ of the total Chinese population. This value is significantly lower in China than in other Asian countries (21\%) and in the world (25.4\%).

According to several studies (Khan et al., 2009; Zhou, 2017; Zolin et al., 2017), several factors are expected to place significant pressure on Chinese food demand. Primarily, these include population growth, urbanisation and industrialisation processes, changes in lifestyle and consumption patterns and shifts in political and economic arrangements. In addition, the increase in agricultural production is hampered by the limited availability of natural resources, such as land and water and rising environmental pollution (Ali et al., 2017; Wang et al., 2017). According to Ali et al. (2017), Chinese natural resources are already subject to extreme human utilisation, which is causing degradation of these resources.

In China, food insecurity is concentrated mostly in rural households, although the improvement of these households' dietary structure, along with the standards of living, has mitigated the gap between them and urban households (Fengying et al., 2010; Qi et al., 2015; Nie and Sousa-Poza, 2016). Chinese food expenditure is increasing in rural and urban areas along with available income. However, its incidence in relation to total available income is reducing, consistent with Engel's law and Bennett's law (Streeten, 1997; Cirera and Masset, 2010).

The overall per capita food intake in China is also growing progressively: in 2000, the daily average per capita intake of calories was 2,814, whereas it reached almost 3,200 calories in 2017. According to FAOSTAT (2020), the average dietary energy supply adequacy has increased between 2000 and 2018, showing the Chinese are on average moving towards higher nutritional standards. Although Chinese diets are prevalently characterised by the consumption of vegetable proteins, they are changing through increased presence of animal products (including meat, fish, animal fats, eggs and dairy products, FAOSTAT, 2020), which implies a greater diversity of food. This tendency is also documented in Zhou et al. (2002) and Lam et al. (2013). The incidence of calorific intake deriving from vegetal products decreased from $81.4 \%$ of total per capita food supply in 2000 to $77.3 \%$ in 2017 (FAOSTAT, 2020). Conversely, the per capita daily intake of calories from animal products rose from $18.6 \%$ to $22.7 \%$ in the same period. The incidence of animal products consumed is much higher in urban areas than in rural areas, even if the gap is reducing slightly over time (especially regarding the intake of protein and fats) (Ghandi and Zhou, 2014). Nevertheless, the dietary structure of the Chinese rural population is characterised predominantly by the consumption of grains.

Therefore, to overcome production constraints and meet the rising food demand, China has increased food imports from the international market and, by the mid-2000s, overall food imports exceeded exports (Zhang, 2019). The long-standing self-sufficiency policy is being replaced by the new strategy of dependence on domestic production with moderate imports. However, the higher reliance on food imports leads to greater exposure to food hazards, endangering both the country's food safety (because of food contamination, for example) and its food security (for instance, because of higher volatility in international food prices).

Food security and trade policies 
BFJ

123,13

\section{Findings and discussion}

Milk is one of the most produced and consumed agricultural commodities worldwide. Given its importance in human nutrition, its growing per capita consumption in developing countries is leading to significant health improvements, especially for the youngest and the eldest generations. In addition to providing human nutrition, milk and milk products play a key role in contributing to reducing poverty by providing employment and revenue in their production and trade. The previous section has shown that the Chinese are increasing their intake of food derived from animal products and diversifying their diets to meet higher nutritional standards. This section shows that the milk sector is an interesting case to consider to provide an explanation of these changes in Chinese diets and to understand how they can be fostered by trade agreements in a country, such as China, with limited natural resources, already largely exploited.

\subsection{The Chinese milk sector}

Since the 2000s, China has experienced rapid growth in the per capita consumption of milk and milk products (Cavapozzi et al., 2020). The average per capita Chinese consumption grew from $4.3 \mathrm{~kg}$ to $12.2 \mathrm{~kg}$ per year in 2000-2018 (National Bureau of Statistics of China, 2019). The average daily per capita intake of calories from milk grew by $183 \%$, and the daily per capita intake of protein and fat (in grams) increased by $172 \%$ and $162 \%$, respectively, in 2000-2018. In the same period, the incidence of individual calorie intake from milk in the total calorie intake has almost tripled, increasing from $0.6 \%$ to $1.6 \%$. Total Chinese milk consumption has increased steadily, from approximately $5.4 \mathrm{bn} \mathrm{kg}$ in 2010 to more than $18 \mathrm{bn}$ $\mathrm{kg}$ in 2018 , and this has been only partially boosted by growth of the population, which increased by $4.3 \%$ from 2010 to 2018 .

However, the per capita consumption of milk and other dairy products in China still does not meet the new dietary guidelines released in 2016 by the Nutrition Society and the National Health and Family Planning Commission (Wang et al., 2016). These recommend a daily dairy per capita consumption of 300 grams, or $109.2 \mathrm{~kg}$ per year (in milk equivalent). According to USDA (2019), less than $30 \%$ of the Chinese population consumed the recommended amount of milk and dairy products in 2019, although milk demand is booming.

There are major differences in milk per-capita consumption between Chinese rural and urban areas, and also among regions (Cavapozzi et al., 2020; Zheng et al., 2015; He et al., 2016; Zhou, 2017; Zeng and Zeng, 2018). In Figure 1 we compare urban and rural per-capita milk consumption between 2000 and 2018 based on data extracted from National Bureau of Statistics of China (2019). In 2000, urban per capita consumption was approximately nine times rural consumption $(9.9 \mathrm{~kg}$ against $1.1 \mathrm{~kg}$ ). The gap has narrowed progressively. In 2018 , the figure was approximately 2.4 times: on average, an urban resident consumes $16.5 \mathrm{~kg}$ of milk per year, compared with $6.9 \mathrm{~kg}$ for his rural counterpart.

Based on National Bureau of Statistics of China (2019), we estimate the income elasticity of per capita consumption of milk, grain (including rice) and meat (including pork) in urban and rural Chinese households. This exercise is important to understand whether the same increase in income has different consequences on the consumption of milk and two other important components of Chinese diets. For each food item, we run the OLS regression of the natural logarithm of per-capita consumption on a constant term and the natural logarithm of the national per-capita GDP, which proxies per-capita income. The coefficient on this explanatory variable in the model measures the average percentage variation in the percapita consumption associated with a one percent variation in per-capita income. Results are summarized in Table 1. Our findings are consistent with the heterogeneity across food items reported in Gandhi and Zhou (2014) for India. Milk income elasticity is very high in rural households (1.37) while being rather low, although positive, in urban households (0.17). 


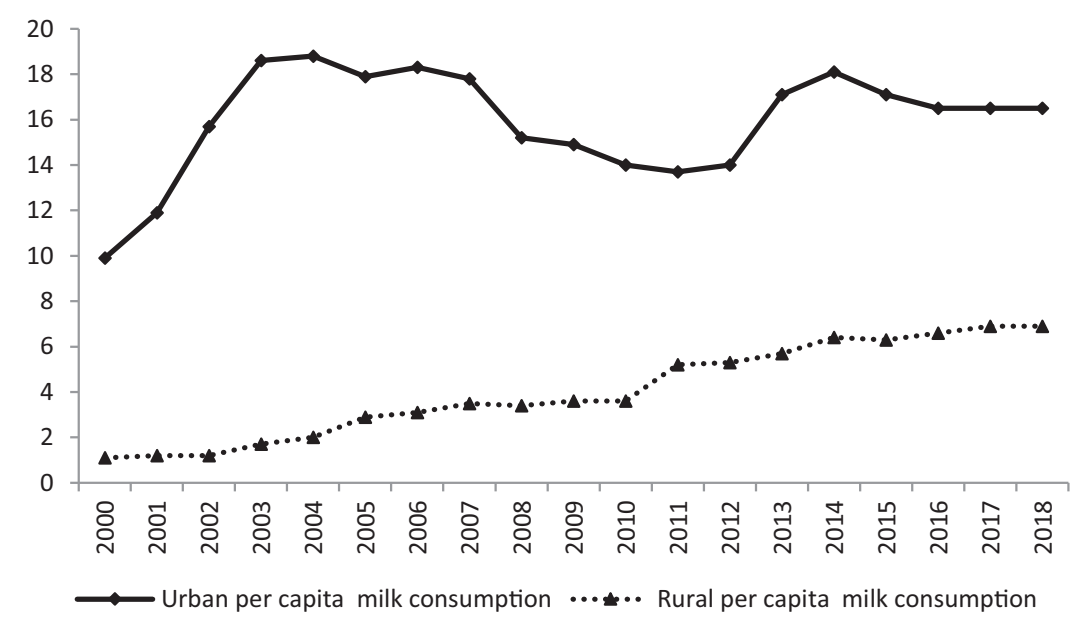

Food security and trade policies

63

Source(s): Authors' elaboration on the National Bureau of Statistics of China (2019)

Figure 1.

Per capita consumption of milk (kg per year) in urban and rural China. Years

2000-2018

\begin{tabular}{lcc}
\hline & Urban households & Rural households \\
\hline Milk & 0.17 & 1.37 \\
Grain & 0.09 & -0.11 \\
Meat & 0.56 & 0.91
\end{tabular}

Source(s): Authors' elaboration on National Bureau of Statistics of China (2019)

Table 1.

Income elasticity of per-capita consumption. Years $2000-2018$

It follows that, as income increases, the demand for milk will grow more than proportionally in rural households and little in urban households (Cavapozzi et al., 2020).

Conversely, grain income elasticity is rather low, but positive in urban Chinese households (0.09) and even negative in rural households (-0.11); therefore, the demand reduces as income grows. This last result is consistent with Bennett's law, which states that as income rises, people eat relatively fewer calorie-dense starchy staple foods and relatively more nutrientrich foods (such as meat and milk). As, on average, rural households are poorer than are urban households; an increase in the income of rural households is more likely to bring them out of poverty and, therefore, has a stronger impact on their food consumption choices (Gale and Huang, 2007). In rural households, an income increase will lead to a significant rising consumption of milk that will partially substitute for grain consumption. In rural households, the income elasticity of meat, instead, is positive and higher than is that in urban households.

However, the expansion of milk production is constrained by the shortage of natural resources. Dairy farming requires a high level of water use and land for feed production. Moreover, it is a source of pollution resulting from the disposal of waste.

To overcome these concerns, China is required to expand its milk imports from international markets to cope with the needs of the population (Ghandi and Zhou, 2014). Drawing data from FAOSTAT (2020), we compare Chinese milk production and imports between 2000 and 2017. The results are summarized by Figure 2. Chinese milk industry increased rapidly until 2008, when it stabilised, and has decreased since 2015. This may be due to physical constraints (e.g. natural resources), a less developed feed industry, epidemic diseases, and stricter environmental regulations (Tao et al., 2016). 
$\mathrm{BFJ}$

123,13

64

Figure 2.

Chinese milk

production and milk imports in China. Years 2000-2017

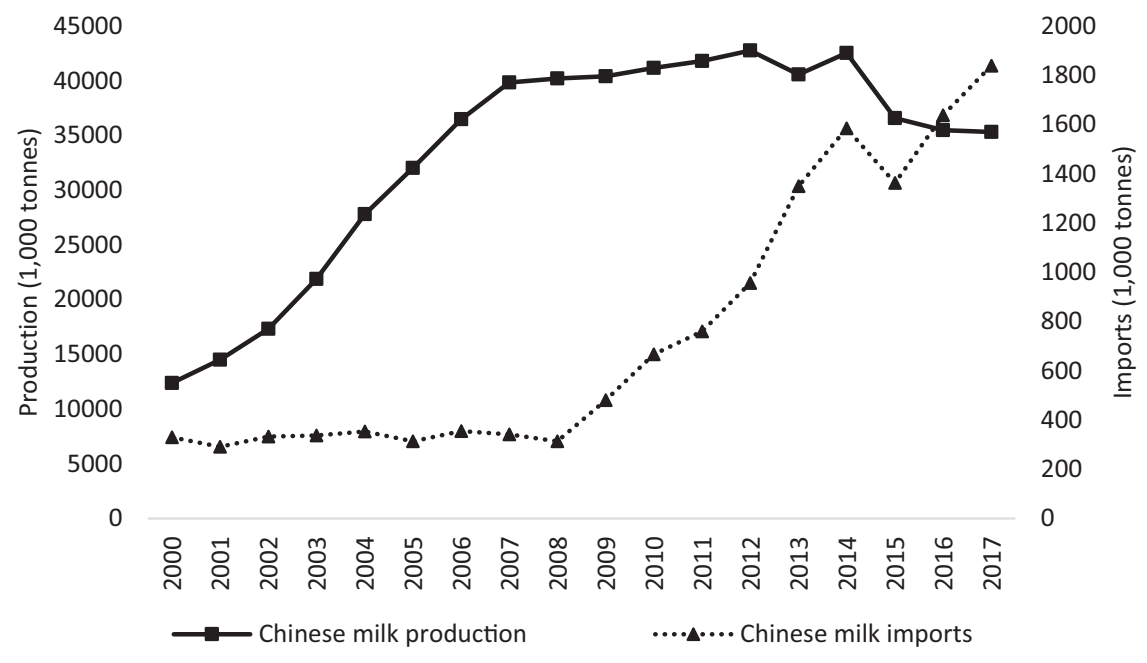

Source(s): Authors' elaboration on FAOSTAT (2020)

The total Chinese milk imports instead remained steady at approximately 300 thousand tonnes per year until the 2008, when the melamine milk scandal generated a change in the trends of both domestic production and imports. After the quality scandal, Chinese consumers started preferring imported dairy products coming from more trusted international markets [such as the European Union (EU), Australia, and New Zealand], as these products were perceived to be healthier and safer than the domestic ones (Fok et al., 2017). Then, imports began to rise sharply, reaching a peak of $1.6 \mathrm{~m}$ tonnes in 2014 . With the introduction of the sanitary and phytosanitary measures and technical barrier to trade measures on dairy imports in China in 2015 (Roberts and Unnevehr, 2005; Tao et al., 2016), milk imports experienced a drop of approximately 200 thousand tonnes, but they began to increase again from 2016, reaching more than 1.8m tonnes in 2017.

The pattern arising from the time series of milk production and imports in Figure 2 is confirmed when looking at the time series for the milk self-sufficiency and importsdependency ratios, which we compute based on FAOSTAT (2020) according to the equations reported below.

$$
\begin{gathered}
\text { Self-sufficiency ratio }=100 \times \frac{\text { Chineseproduction }}{\text { Chineseproduction }+ \text { Chineseimports }- \text { Chinese exports }} \\
\text { Imports-dependency ratio }=100 \times \frac{\text { Chineseimports }}{\text { Chineseproduction }+ \text { Chineseimports }- \text { Chinese exports }}
\end{gathered}
$$

The milk self-sufficiency and import dependency ratios are plotted in Figure 3. The milk selfsufficiency ratio reached a peak of $99.5 \%$ (milk consumption is almost equal to domestic milk production) in 2008, and then began decreasing until the present. The milk importsdependency ratio reached a minimum of $0.8 \%$ in 2008 and then began to rise.

These two complementary trends show that the capacity of China to satisfy milk needs from its own domestic production is declining over time, although it remains at a very high 


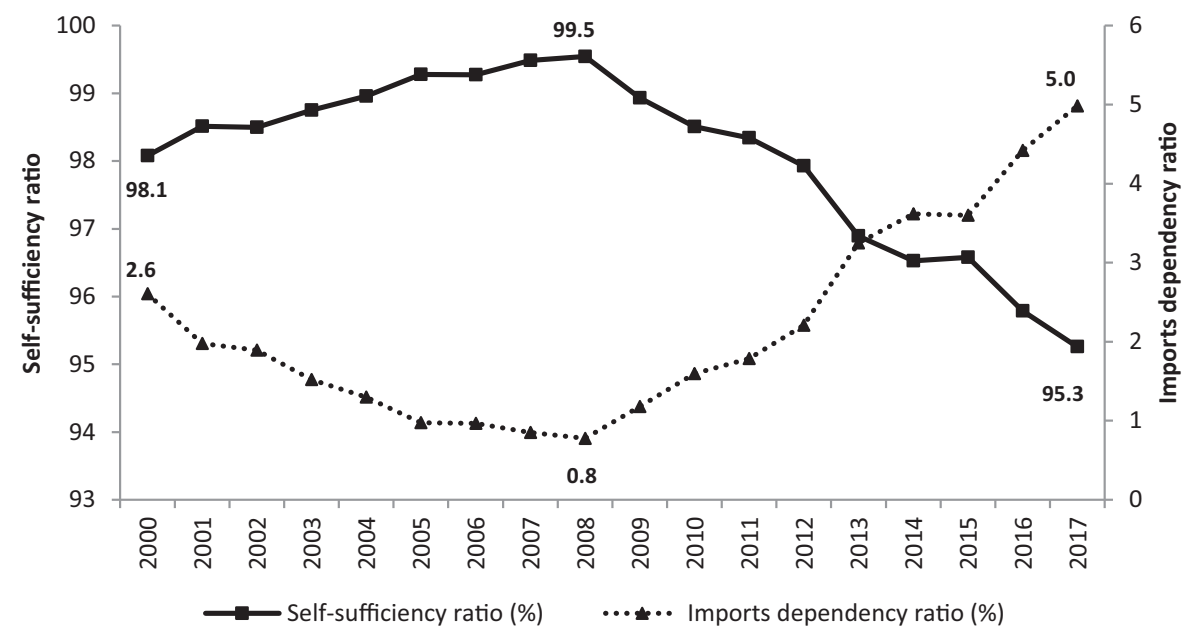

Source(s): Authors' elaboration on FAOSTAT (2020)
Food security and trade policies

65

Figure 3. Milk self-sufficiency ratio and imports' dependency ratio in

China. Years 2000-2017

level (the self-sufficiency ratio is higher than $95 \%$ in 2017). Therefore, imports from international markets are required and will be required even more in the future. According to OECD-FAO (2019), China not only remains (since 2010-2011) the largest importer worldwide of milk and milk products but also is expected to further expand its milk import share along with stricter safeguard measures.

One consequence of China's necessity to import is the increase in the number of bilateral and multilateral agreements to facilitate and secure imports. According to Clapp (2017), however, developing countries like China, characterised by a very large population, would benefit from reducing their reliance on international imports, rather than signing agreements to ensure that the population's food needs are satisfied. This holds true, especially if a consistent part of people's available income is devoted to food consumption and, therefore, health and nutrition are particularly sensitive to food price trends, strongly affected by fluctuations in the amounts of food purchased by large countries. It follows that a relative higher self-sufficiency ratio, together with a relative lower imports' dependency ratio, would contribute to support stability in the food supply of the country. Although this argument is correct in principle, it is worth remembering that the expansion of China's production of milk faces several constraints.

Lu et al. (2015) and Huang and Yang (2017) point out the ongoing deterioration of land and water resources and the intensification of the environmental degradation. The growth in intensive agriculture and breeding has highly stressed the limited natural resources and the rural environment of the country. The rising water demand deriving from urbanisation and industrialization and the increasing pollution and soil quality degradation are further threats to environmental sustainability (Huang and Yang, 2017). The dairy sector, in particular, has a very considerable environmental impact, related mainly to soil degradation, air and water pollution, water utilization and loss of biodiversity (Haas et al., 2019). In addition, it is responsible for a very large part of $\mathrm{CO} 2$ emissions (Morais et al., 2018). China does not have enough land resources to develop numerous small-scale animal farms to meet the growing demand for animal food products (Hu et al., 2017). Therefore, the expansion of intensive animal farming in China has intensified not only environmental concerns but also public 
BFJ

123,13

health risks. Intensive breeding is associated with a higher risk of pathogens, which may be infectious to humans (Hu et al., 2017). Finally, animal feeding is also an issue, as it is based mainly on soybeans, for which China relies on imports, and this is a matter of current concern because of the China-US trade war. Improving the self-sufficiency ratio of the milk sector might increase the dependence of China on the countries guaranteeing the availability of the inputs necessary for this industry (Huang et al., 2017).

\subsection{Trade barriers and China's top milk suppliers}

Food security is historically an important point in trade negotiations (Margulis, 2017; Nakuja and Kerr, 2018). There is an increasing awareness in the literature about the positive role of trade opening in improving a country's food security (Susanto, 2007; MacLaren and Yabuki, 2012; Weiming, and Ying, 2012; OECD, 2015).

Since its accession to the WTO in 2001, China has developed a considerable number of bilateral and multilateral regional trade agreements aimed at removing technical barriers to trade and strengthening economic cooperation with other economies. Currently, China has 17 regional trade agreements signed and implemented and eight under construction. Our work focuses on regional trade agreements that are particularly important for the milk sector in China. The three main milk exporters in China are New Zealand, the EU and Australia. Unlike the EU, both New Zealand and Australia have a free trade agreement (FTA) in force with China. Both countries are predominantly free-trade oriented, have a strong primary sector and are attractive trade partners for China, and vice-versa. Moreover, New Zealand, subsequently followed by Australia, was the first country to recognise China as a market economy. Whereas, despite the gradual strengthening of cooperation between China and the $\mathrm{EU}$, there are differences, particularly on the economic front, which have prevented the conclusion of an agreement.

New Zealand is the major dairy exporter to China. Since the FTA came into force in 2008, thanks to the progressive elimination of trade barriers, exports and imports of goods and services have more than tripled from $\$ 9 \mathrm{bn}$ to over $\$ 32 \mathrm{bn}$ in 2008-2018. This trade creation has mainly affected the most important export category of New Zealand, which is "food and live animals" and includes dairy products. According to Ungor and Verevis (2019), exports to China related to this sector would have been $185.5 \%$ lower without the agreement.

For what concerns dairy products, the FTA authorised the removal of China's tariff on butter, liquid milk and cheese (by 2017), those on skim and whole milk powders (by 2019) and on other dairy products by 2024. In addition, the agreement established a quantity-based safeguard on several dairy products (including liquid milk, cheese, butter and all milk powders): exports above the safeguard trigger levels are subject to duties (Ministry of Foreign Affairs and Trade of New Zealand, 2008). The upgraded 2020 China-New Zealand FTA confirms the existing conditions regarding dairy products without improvements to the dairy safeguard arrangements. However, by January 2024 tariffs will be eliminated for most dairy products, therefore, New Zealand will have an easier and larger access to China with respect to other countries (Government of New Zealand, 2019).

The Australia-China FTA, effective since 2015, is also important for dairy products. China is the Australia's largest market for dairy exports. The Australia-China FTA is also progressively eliminating tariffs across all Australian dairy products by 2026 (Australian Government - Department of Foreign Affairs and Trade, 2018). Unlike the FTA between China and New Zealand, the FTA with Australia does not have restrictive safeguard measures on most dairy products. This provides Australia with a comparative advantage with respect to New Zealand in accessing the Chinese market. Lack of safeguard measures might be due to the lower production capacity of Australian farms, which cannot substantially decrease the domestic market share of Chinese milk producers. 
In Figure 4, we report the milk imports of China from its top suppliers between 2000 and 2017. Consistently with Figures 2 and 3, data are extracted from FAOSTAT (2020). As shown in Figure 2, China imported 1.8m tonnes of milk in 2017 ( $+459 \%$ as compared with 2010 ), for a value of $\$ 5.2 \mathrm{bn}$ dollars ( $+2.9 \mathrm{bn}$ dollars as compared with 2010$)$. Figure 4 shows a sharp increase in New Zealand milk exports towards China since 2008, facilitated by the preferential tariffs under the New Zealand-China FTA of 2008 and boosted by the melamine milk scandal affecting Chinese domestic production. In just one year, (2008-2009) milk exports grown by 195 thousand tonnes $(+331 \%)$, while from 2008 to 2017 exports grown by 710 thousand tonnes $(+1,205 \%)$ reaching 770 thousand tonnes. New Zealand is China's top milk supplier covering about $42 \%$ of total China's imports in 2017. A significant reduction of New Zealand milk exports occurred in 2014-2015 after New Zealand's milk scandal of 2013 (Xu and Wu, 2018) and probably due to an increased global competition (in 2015, the EU milk quota were abolished and the China-Australia FTA entered into force). However, from $2016 \mathrm{New}$ Zealand exports to China started recovering.

Australia also experienced an increase in milk exports to China after the entry into force of the FTA in 2015 (+46\% in 2015-2017 equal to 53.9 thousand tonnes).

Currently, a trade agreement between the EU and China does not exist, it follows that the $\mathrm{EU}$ is in a disadvantageous position compared with its main competitors in milk trade with China not just for physical distance. However, the size of the market plays a role in favour of the EU, for a much larger population and a higher capacity than that of New Zealand and Australia. The lack of a trade agreement can be indeed one of the reasons explaining the lower increase of the EU milk exports to China after the melamine scandal of 2008, which instead boosted the New Zealand exports. Despite that, the EU is the second top China's milk supplier with a $28 \%$ share in 2017 . The EU, driven by Germany, accounts for over $50 \%$ of the fluid milk imports into China (USDA, 2019). The abolition of milk quota in the EU had a key role in EU milk exports expansion to China (Cavapozzi et al., 2020). The excess of production generated, in fact, fuelled EU trade flows, especially towards international markets where the level of per capita consumption was still low and could substantially increase. Hence, the EU milk exports towards China experienced a major increment from 2013-2015, when countries

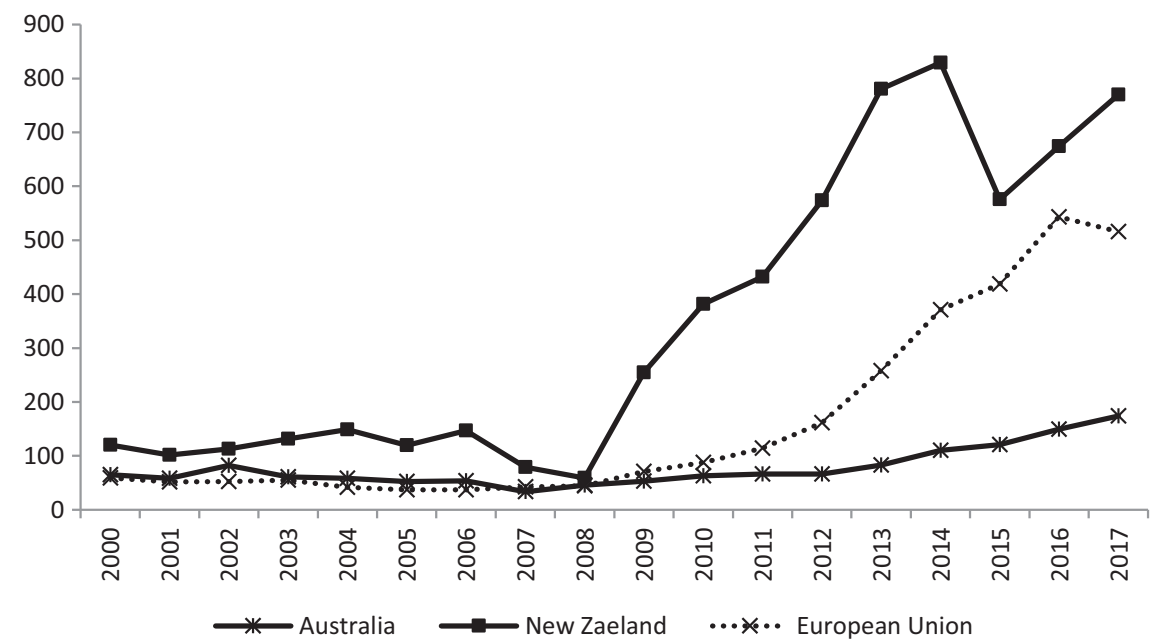

Source(s): Authors' elaboration on FAOSTAT (2020)

Food security and trade policies

Figure 4. Top China's milk suppliers (thousand tonnes). Years 2000-2017 
$\mathrm{BFJ}$

123,13

68 where adapting to the imminent quota abolition and then continued increasing, although at lower rate.

European dairy products would further benefit from a trade opening via the reduction and abolishment of tariffs and non-tariff barriers, especially since EU milk production is expected to expand by $5.8 \%$ from 2018 to 2028 (OECD-FAO, 2019). The additional foreign demand enhanced by trade agreements, in fact, could translate into a significant growth rates for exports, production and producer prices as well as jobs creation and value added for the milk sector. A free trade agreement can also support the EU in the competition with New Zealand and Australia in the exports to China. Albeit more distant from China and then exposed to higher transportation costs, the production capacity of EU is bigger than that of its competitors. A trade agreement might make EU in the position to exploit this advantage (Zolin and Uprasen, 2018). This argument reinforces when considering that countries specialised their production in industries in which they have higher comparative advantages. It is unlikely that China will increase substantially its milk domestic production in the future, as its main comparative advantages lie in other industries, for instance the manufacturing sector. Instead, New Zealand, EU and Australia have stronger comparative advantages in the milk production, which call for international trade policies facilitating their milk exports to China.

\section{Concluding remarks}

This paper documents that the milk per-capita consumption of Chinese is increasing. Although it remains higher in urban areas, the gap with rural areas has reduced from 9 to 2.4 times between 2000 and 2018. According to our elasticity estimates, increases in the percapita income of Chinese will raise their milk consumption, which will grow more than proportionally in rural areas.

The gap between Chinese demand for milk and domestic production is currently met by imports. China's top milk suppliers are New Zealand, the EU and Australia. The milk production of these countries has been impacted by alternative trade liberalisation policies. On the one hand, New Zealand and Australia has signed free trade agreements with China in 2008 and 2015, respectively. On the other hand, the EU removed milk quota in 2015. Based on data drawn from FAOSTAT, we show that the exports to China of all these countries have increased in the period following the implementation of these trade liberalisation policies.

Trade liberalisation is associated with benefits for both China and its milk suppliers. On the one hand, exporting country farmers have access to a larger market (China holds almost a fifth of the global share). New Zealand and Australia can recognise to their milk farmers relatively high prices since the exported quantity does not affect the domestic market. The EU can export the excess milk produced, resulting from the abolition of the milk quota. On the other hand, China, can satisfy the domestic primary needs of the population not only in quantitative but also in qualitative terms and guarantee access to milk and milk products, which are nutritionally important and contribute to diversifying the typical vegetableoriented diets of the Chinese.

From the point of view of further research, it would be interesting to verify on the one hand whether these free trade agreements have produced a trade diversion or creation using, by way of example, the gravitational model. On the other hand, it could be studied to what extent the liberalization of the milk market affects the environmental conditions of the most involved producing countries (such as the Netherlands). The production of milk is, in fact, one of the most polluting activities. From the public policies perspective, the case examined is of particular interest as it intervenes on a strategic objective, such as food security and safety, and it could represent a useful case study in analysing future consumption trends. 
Trade agreements and the removal of barriers could be effective responses to protectionist pressures and to food security concerns due to the global economic crisis that the coronavirus is causing.

\section{References}

Ali, T., Huang, J., Wang, J. and Xie, W. (2017), "Global footprints of water and land resources through China's food trade”, Global Food Security, Vol. 12, pp. 139-145, doi: 10.1016/j.gfs.2016.11.003.

Anderson, K., Rausser, G. and Swinnen, J. (2013), "Political economy of public policies: insight from distortion to agricultural and food markets", Journal of Economic Literature, Vol. 51 No. 2, pp. $423-477$.

Australian Government - Department of Foreign Affairs and Trade (2018), "ChAFTA fact sheet: agriculture and processed food", available at: https:/dfat.gov.au/trade/agreements/in-force/ chafta/fact-sheets/Documents/chafta-fact-sheet-agriculture-and-processed-food.pdf (accessed 13 December 2019).

Cavapozzi, D., Mazzarolo, M. and Zolin, M.B. (2020), "Abolition of a trade barrier: the case of the EU milk quota and the Chinese market", Transition Studies Review, Vol. 27 No. 2, pp. 51-68, 9781786305701.

Cirera, X. and Masset, E. (2010), "Income distribution trends and future food demand", Philosophical Transactions of the Royal Society B: Biological Sciences, Vol. 365 No. 1554, pp. 2821-2834.

Clapp, J. (2017), "Food self-sufficiency: making sense of it, and when it makes sense", Food Policy, Vol. 66, pp. 88-96.

FAO, IFAD, UNICEF, WFP and WHO (2019), "The state of food security and nutrition in the world 2019. Safeguarding against economic slowdowns and downturns", available at: http://www.fao. org/3/ca5162en/ca5162en.pdf (accessed 3 December 2019).

FAOSTAT (2020), "FAO dataset", available at: http://www.fao.org/faostat/en/\#data (accessed January-March 2020).

Fengying, N., Jieying, B. and Xuebiao, Z. (2010). "Study on China's food security status”, Agriculture and Agricultural Science Procedia, Vol. 1, pp. 301-310.

Fok, A., Hui, M. and Hui, A. (2017), "China dairy downstream is key", DBS Asian insight - Sector Briefing, Vol. 52, pp. 1-60.

Gale, H.F. and Huang, K. (2007), "Demand for food quantity and quality in China”, USDA, Economic Research Report No. 32. available at: https://ssrn.com/abstract=1739091 (accessed 4 February 2020).

Gandhi, V.P. and Zhou, Z. (2014), "Food demand and the food security challenge with rapid economic growth in the emerging economies of India and China”, Food Research International, Vol. 63, pp. 108-124.

Government of New Zealand (2019), "NZ-China FTA upgrade negotiations conclude, 4 November 2019", available at: https://www.beehive.govt.nz/release/nz-china-fta-upgrade-negotiationsconclude (accessed 2 April 2020).

Haas, R., Schnepps, A., Pichler, A. and Meixner, O. (2019), "Cow milk versus plant-based milk substitutes: a comparison of product image and motivational structure of consumption", Sustainability, Vol. 11 No. 18, pp. 1-25.

He, Y., Yang, X., Xia, J., Zhao, L. and Yang, Y. (2016), "Consumption of meat and dairy products in China: a review", Proceedings of the Nutrition Society, Vol. 75 No. 3, pp. 385-391.

Hu, Y., Cheng, H. and Tao, S. (2017), "Environmental and human health challenges of industrial livestock and poultry farming in China and their mitigation", Environment International, Vol. 107, pp. 111-130.

Huang, J. and Yang, G. (2017), "Understanding recent challenges and new food policy in China”, Global Food Security, Vol. 12, pp. 119-126.
Food security and trade policies 
BFJ 123,13

Huang, J.K., Wei, W., Qi, C. and Wei, X.I.E. (2017), "The prospects for China's food security and imports: will China starve the world via imports?”, Journal of integrative agriculture, Vol. 16 No. 12, pp. 2933-2944.

Khan, S., Hanjra, M.A. and Mu, J. (2009), "Water management and crop production for food security in China: a review”, Agricultural Water Management, Vol. 96 No. 3, pp. 349-360.

Lam, H.M., Remais, J., Fung, M.C., Xu, L. and Sun, S.S.M. (2013), "Food supply and food safety issues in China”, The Lancet, Vol. 381 No. 9882, pp. 2044-2053.

Lu, Y., Jenkins, A., Ferrier, R.C., Bailey, M., Gordon, I.J., Song, S. and Feng, Z. (2015), “Addressing China's grand challenge of achieving food security while ensuring environmental sustainability", Science advances, Vol. 1 No. 1, e1400039.

MacLaren, D. and Yabuki, N. (2012), "Regional trade agreements and food security: introduction and overview", FAO, Regional Trade Agreements and Food Security in Asia, FAO, Bangkok.

Margulis, M. (2017), "The forgotten history of food security in multilateral trade negotiations", World Trade Review, Vol. 16 No. 1, pp. 25-57.

Ministry of Foreign Affairs and Trade of New Zealand (2008), "Key outcomes: New Zealand-China free trade agreement", available at: https:/www.mfat.govt.nz/assets/FTAs-agreements-in-force/ China-FTA/Key-outcomes.pdf (accessed 13 December 2019).

Morais, T.G., Teixeira, R.F., Rodrigues, N.R. and Domingos, T. (2018), "Carbon footprint of milk from pasture-based dairy farms in Azores, Portugal”, Sustainability, Vol. 10 No. 10, p. 3658.

Nakuja, T. and Kerr, W.A. (2018), "Food security though public stockholdings and trade distortions", British Food Journal, Vol. 120 No. 5, pp. 1089-1105, doi: 10.1108/BFJ-07-2017-0391 (accessed 13 December 2019).

National Bureau of Statistics of China (2019), "China statistical yearbook of 2019", available at: http:// www.stats.gov.cn/tjsj/ndsj/2019/indexeh.htm (accessed 12 January- 20 March 2020).

Nie, P. and Sousa-Poza, A. (2016), "A fresh look at calorie-income elasticities in China", China Agricultural Economic Review, Vol. 8 No. 1, pp. 55-80.

OECD (2015), Regional Trade Agreements and Agriculture, OECD Food, Agriculture and Fisheries Papers, No. 79, OECD Publishing, Paris.

OECD-FAO (2019), OECD-FAO Agricultural Outlook 2019-2028, OECD Publishing, Paris. doi: 10. 1787/agr_outlook-2019-en (accessed 9 January 2020).

Qi, X., Vitousek, P.M. and Liu, L. (2015), "Identification and evaluation of risk factors related to provincial food insecurity in China", Journal of Risk Research, Vol. 18 No. 9, pp. 1184-1202.

Roberts, D. and Unnevehr, L. (2005), "Resolving trade disputes arising from trends in food safety regulation: the role of the multilateral governance framework", World Trade Review, Vol. 4 No. 3, pp. 469-497.

Streeten, P.P. (1997), “Thinking about development”, Raffaele Mattioli Foundation, Cambridge University Press, Cambridge.

Susanto, D., Rosson, C.P. III and Adcock, F.J. (2007), "Trade creation and trade diversion in the North American Free Trade Agreement: the case of the agricultural sector", Journal of Agricultural and Applied Economics, Southern Agricultural Economics Association, Vol. 39 No. 1, pp. 1-14.

Tao, H., Luckstead, J., Zhao, L. and Xie, C. (2016), "Estimating restrictiveness of SPS measures for China's dairy imports", The International Food and Agribusiness Management Review, Vol. 19, pp. 101-124.

UN (2020), "Policy brief: the impacts of COVID-19 on food security and nutrition", available at: https:// www.un.org/sites/un2.un.org/files/sg_policy_brief_on_covid_impact_on_food_security.pdf (accessed 02 January 2021).

Ungor, M. and Verevis, S. (2019), "What has New Zealand gained from the FTA with China? Two counterfactual analyses", Economic Discussion Papers No 1906, School of Business Collection, 
University of Otago, available at: https://www.otago.ac.nz/economics/otago709660.pdf (accessed 13 December 2019).

USDA (2019), "China - peoples republic of dairy and products semi-annual higher profits support increased fluid milk production", available at: https://apps.fas.usda.gov/newgainapi/api/report/ downloadreportbyfilename? filename $=$ Dairy $\% 20$ and $\% 20$ Products $\% 20$ Semi-annual_Beijing China\%20-\%20Peoples\%20Republic\%20of_7-25-2019.pdf (accessed 19 December 2019).

Wang, O. (2020), “China food security: how's it going and why's it important?", South China Morning Post, 29 November 2020. available at: https:/www.scmp.com/economy/china-economy/article/ 3111623/china-food-security-hows-it-going-and-whys-it-important?utm_source $=$ copy_ link\&utm_medium=share_widget\&utm_campaign=3111623 (accessed 02 January 2021).

Wang, S.S., Lay, S., Yu, H.N. and Shen, S.R. (2016), "Dietary guidelines for Chinese residents (2016): comments and comparisons", Journal of Zhejiang University - Science B, Vol. 17 No. 9, pp. 649-656.

Wang, J., Li, Y., Huang, J., Yan, T. and Sun, T. (2017), "Growing water scarcity, food security and government responses in China”, Global Food Security, Vol. 14 Supplement C, pp. 9-17.

Weiming, T. and Ying, G. (2012), "The effects of trade liberalization on the development of China's soybean sector", FAO, Office for Asia and Pacific, Regional Trade Agreements and Food Security in Asia, FAO, Bangkok, pp. 339-375.

$\mathrm{Xu}, \mathrm{J}$. and $\mathrm{Wu}, \mathrm{Y}$. (2018), "A comparative study of the role of Australia and New Zealand in sustainable dairy competition in the Chinese market after the dairy safety scandals", International Journal of Environmental Research and Public Health, Vol. 15 No. 12, p. 2880.

Zeng, Q. and Zeng, Y. (2018), "Eating out and getting fat? A comparative study between urban and rural China", Appetite, Vol. 120, pp. 409-415.

Zhang, H. (2019), "Paradigm shift in China's food security strategy", in Zhang, H. (Ed.), Securing the 'Rice Bowl, Palgrave Macmillan, Singapore, pp. 29-63.

Zheng, Z., Henneberry, S.R., Zhao, Y. and Gao, Y.J. (2015). "Income growth, urbanization, and food demand in China", 2015 AAEA \& WAEA Joint Annual Meeting, July 26-28, San Francisco, California 205105, Agricultural and Applied Economics Association No. 330-201613820. 2015.

Zhou, Z.Y. (2017), Achieving Food Security in china: The Challenges Ahead, Taylor \& Francis, Adelaide.

Zhou, Z.Y., Tian, W.M. and Zhou, J.L. (2002), "The emerging dairy economy in China: production, consumption and trade prospects", Australasian Agribusiness Review, Vol. 10, Paper 8.

Zolin, M.B. and Uprasen, U. (2018), "Trade creation and diversion: effects of EU enlargement on agricultural and food products and selected Asian countries", Asia Europe Journal, Vol. 16, pp. 351-373.

Zolin, M.B., Cassin, M., Mannino, I., Taylor, R. and Jaussaud, J. (2017), "Food security, food safety and pesticides: China and the EU compared", China's Global Political Economy. Managerial Perspectives, Routledge Taylor\&Francis Group, London, pp. 253-277, ISBN 978-1-138-103733978-1-315-10256-6.

\section{About the authors}

Maria Bruna Zolin is Professor of Economics-Rural Development and Commodity Markets at the Ca' Foscari University of Venice. Her academic research focuses primarily on agricultural and food products, the economics of rural development, international trade, the environment and business development, and European policy. She has been Deputy Head of the School of Asian Studies and Business Management at Ca' Foscari University. She has served as an expert for the FAO in Rome and a Visiting Professor in several universities. She has published mainly in the areas of agricultural markets and rural development policies. Maria Bruna Zolin is the corresponding author and can be contacted at: zolin@unive.it

Food security and trade policies 
BFJ

123,13

Danilo Cavapozzi is Associate Professor of Economic Policy at the Ca' Foscari University of Venice. He holds a Laurea degree in Statistics and Economics and a $\mathrm{PhD}$ in Economics and Management from the University of Padua. His research interests cover applied microeconomics, microeconometrics, labour economics, household economics and the economics of ageing.

Martina Mazzarolo is research assistant at the Ca' Foscari University of Venice. She holds a Bachelor degree and a Master degree in Economics from the same university. Her main research interests cover the economics of rural development, the evaluation of public policies in rural areas and international trade.

For instructions on how to order reprints of this article, please visit our website: www.emeraldgrouppublishing.com/licensing/reprints.htm Or contact us for further details: permissions@emeraldinsight.com 